\title{
Enhancing Business Performance in the Banking Sector through High-Performance Human Resources Practices: A Conceptual Framework
}

\section{Miad Alqahtani, Azman Hashim, Syaharizatul Noorizwan Binti Muktar}

To Link this Article: http://dx.doi.org/10.6007/IJARBSS/v11-i12/11810 DOI:10.6007/IJARBSS/v11-i12/11810

Received: 09 October 2021, Revised: 11 November 2021, Accepted: 28 November 2021

Published Online: 17 December 2021

In-Text Citation: (Alqahtani et al., 2021)

To Cite this Article: Alqahtani, M., Hashim, A., \& Muktar, S. N. B. (2021). Enhancing Business Performance in the Banking Sector through High-Performance Human Resources Practices: A Conceptual Framework. International Journal of Academic Research in Business and Social Sciences, 11(12), 2221-2234.

\section{Copyright: @ 2021 The Author(s)}

Published by Human Resource Management Academic Research Society (www.hrmars.com) This article is published under the Creative Commons Attribution (CC BY 4.0) license. Anyone may reproduce, distribute, translate and create derivative works of this article (for both commercial and non0-commercial purposes), subject to full attribution to the original publication and authors. The full terms of this license may be seen at: http://creativecommons.org/licences/by/4.0/legalcode

Vol. 11, No. 12, 2021, Pg. 2221- 2234

Full Terms \& Conditions of access and use can be found at http://hrmars.com/index.php/pages/detail/publication-ethics 


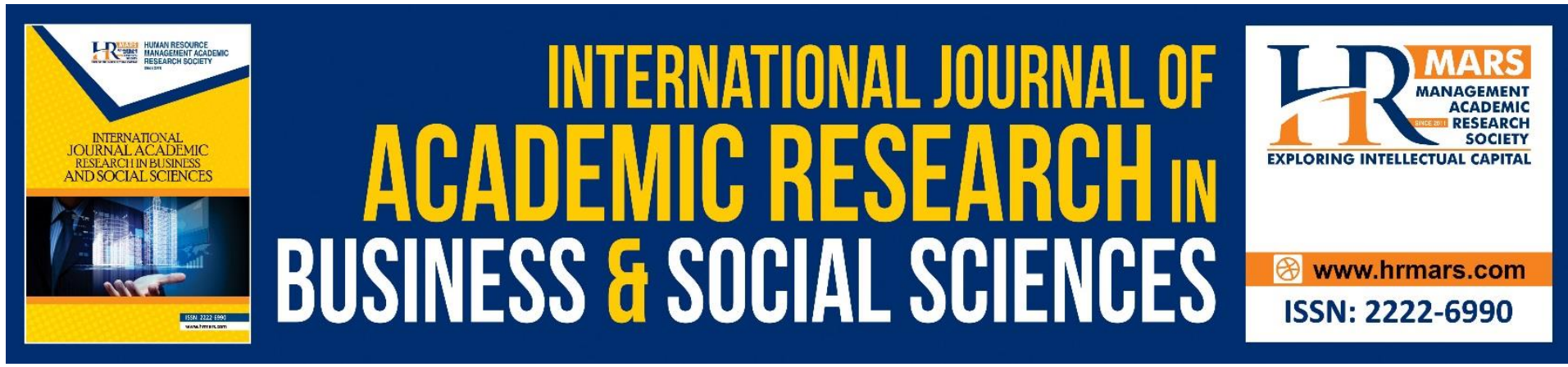

\title{
Enhancing Business Performance in the Banking Sector through High-Performance Human Resources Practices: A Conceptual Framework
}

\author{
${ }^{1}$ Miad Alqahtani, ${ }^{2}$ Azman Hashim, ${ }^{3}$ Dr. Syaharizatul Noorizwan \\ Binti Muktar \\ ${ }^{1}$ PhD Scholar, Azman Hashim International Business School, University Teknologi Malaysia, \\ ${ }^{2}$ Assoc. Prof. Dr. Nomahaza Binti Mahadi1, ${ }^{2}$ International Business School, University \\ Teknologi Malaysia, ${ }^{3}$ Azman Hashim International Business School, University Teknologi \\ Malaysia \\ Email:mmiad@graduate.utm.my, nomahaza.kl@utm.my, izatul@utm.my
}

\begin{abstract}
The purpose of this study is to develop a conceptual framework of the relationship between High-Performance Human Resources Practices (HPHRPs) and business performance provide the importance to conduct this study. Based on an extensive review of the past studies, the relationship between human resource practices and business performance remains unclear, and ambiguity exists about the mechanism of how HPHRPs influence business performance. Despite these studies, human resource management practices have been suggested to be studied to determine the relationship between business performance. Thus, this concept paper investigates the relationship between three HPHRPs (training and development, employees' empowerment, compensation and rewards) and business performance. Based on Ability-Motivation-Opportunity (AMO) and the Resource-Based View (RBV) theories, highperformance human resources practices are the best way of employing vital internal resources that influence business performance. Therefore, this conceptual paper explores the role of High-Performance Human Resources Practices (HPHRPs) on business performance. This paper contributes to the body of knowledge towards understanding the function of HPHRPs on business performance, particularly when organizations rely heavily on labour force skills to gain a competitive advantage. More importantly, this paper will provide future directions to academics, practitioners, and policy-makers in understanding HPHRPs from a business performance perspective.
\end{abstract}

Keywords: High-Performance Human Resources Practices, Business Performance, Innovation, Banking

\section{Introduction}

Organizational performance has become critical for sustainability and competitiveness in a competitive business environment. Therefore, performance plays a crucial role in every organization (Imran et al., 2015). The performance of an organization is subject to individuals. Thus, the ultimate contribution common to all organizations has been widely focused on 
increasing its human resources (Sheehan, 2014). Employees are known as the most crucial assets in the organization; thus, Ulrich and Lake (1991) claimed that people might be the ultimate source of competitive advantage. Accordingly, In the last two decades, a great interest in research in different disciplines has been devoted to discovering the predictors and effects of high-performance human resources practices-performance (HPHRPs) linkage, precisely, the influence of selected dimensions of HPHRPs on organizational performance (Khoreva \& Wechtler, 2018; Koopmans et al., 2016; Van De Voorde \& Beijer, 2015).

On the other hand, human resources management is imperative for all organizations, specifically service providers like the banking sector. Hence, the banking sector is highly service-oriented in its operations and structure and relies heavily on labour force skills to gain a competitive advantage (Cherif, 2020). The banking sector depends mainly on its employees' quality and competence. Therefore, this sector has to pay more attention to its human resources because it maximizes employees' competencies (Saleem \& Khurshid, 2014). Besides, human resource management practices can generate organizations' characteristics by intelligence, flexibility, and competence compared to their competitors (Nancy, 2013).

Consequently, in a competitive business environment, organizations must adopt highperformance human resource practices (HPHRPs) to cope with the growing competitive environment. For example, consumer neuroscience studies could be impactful and helpful to examine the effect of emotional and cognitive processes on consumers' behaviour (see Alsharif et al., 2021a;2021b; 2021c; 2021d). HPHRPs are a collection of various human resource $(H R)$ practices developed to improve employees' skills and competencies within an organization (Chahal et al., 2016). Unlike traditional human resources practices, HPHRPs encourage and support the employees to achieve the organizational goals and, thus, work harder to reach them by developing committed personnel empowered to conduct tasks invaluable (Arthur, 1994). HPHRPs are intended to enhance the competency of the organization through producing synergistic effects and improving performance (MacDuffie, 1995).

Over the last three decades, there has been a growing interest in examining the effect of human resource practices on organizational performance (e.g., Absar et al., 2010; Aktar et al., 2012; Demortier et al., 2014; Jackson et al., 2014; Messersmith et al., 2011; Obeidat et al., 2016; Singh et al., 2016; Wright et al., 2005). Jointly, these studies have shown various HR practices foster organizational performance and revealed that human resource practices are positively associated with several organization-level outcome constructs such as financial performance, productivity, sales, innovation, and market share. On the other hand, the Nonfinancial performance, i.e., quality, customer satisfaction, and customer loyalty (e.g., Bontis et al., 2007; Igbudu et al., 2018; Sadek et al., 2012; Scrace \& McAulay, 1997). Despite this increasing volume of literature, several scholars claimed that research stream on the association between HPHRPs and the business performance had provided an insufficient understanding of the effects of HPHRPs on organizational-level performance (e.g., Alfes et al., 2013; Den Hartog et al., 2013; Kehoe \& Wright, 2013; Messersmith et al., 2011; Van De Voorde \& Beijer, 2015). Further, ambiguity still exists about how the bundle of HRM practices may ultimately help the organization's competitive edge. Thus a deeper understanding of managing human resources in the banking sector context is vital. Therefore, this study aims 
to contribute to this growing area of research by investigating the HPHRPs that may contribute to the banks' success.

\section{Literature Review}

\section{High-Performance Human Resource Practices (HPHRPs)}

The concept of High-performance HR practices (HPHRPs) has emerged in the last two decades. It is defined as HR programs to improve an organization's effectiveness by creating conditions that allow employees to engage and work hard to fulfil their objectives (Whitener, 2001). HPHRPs involve preparation, assessment of results, knowledge sharing, and involvement and participation (Jiang et al., 2015). HPHRPs are defined as a set of closely related human resource practices, including training and development, performance management and compensation, high employee participation, communication, and staffing (Armstrong \& Baron, 2009; Boxall \& Macky, 2009).

On the other hand, Brewster et al (2016) argued that HPHRPs act as the intersection between an organization's strategic planning and strategic HPHRP. HPHRPs include recruitment and selection, performance appraisal, sharing information, productivity, future job requirements, and determining the number and type of employees needed to achieve strategic organization goals (Akhigbe, 2019). Hence, HPHRPs enhance these skills and capabilities through training, performance management, participation, and rewards (Jouda et al., 2016; Karam et al., 2017). Three significant HPHRPs practices benefit employees and organizations draw considerable attention (Jiang \& Messersmith, 2018): First, employees' social and human capital and, by extension, their market values significantly increase by the problem solving and technical training built into high-performance work systems. Chahal et al (2016) claimed that despite the substantial research on high-performance HR practices, there is still a lack of agreement on how high-performance HR practices affect business performance. The proposed conceptual model includes selected HPHRPs (training and development, employees' empowerment, compensation and rewards) that enhance the organizational performance by innovation as a mediator.

\section{Training and Development}

Training and development are the most crucial factors in business success. It can improve both organization and employees (Boadu et al., 2014; Khan et al., 2011). Training and development are essential to enhance the capabilities of employees. Training and development aim to develop and execute training programs positively influencing organizational performance (Smith \& Mazin, 2011). Rowden and Conine (2005) believe that well-trained employees will better meet the demands of their clients and partners. Taufek and Mustafa (2018) argued that a successful well-designed training program moves the employee from the problematic barrier to the ultimate stage and can perform the tasks effectively. Elnaga and Imran (2013) argued that the more well-trained employee, the more satisfied they will be with their duties; thus, increasing the productivity and profitability of their firm.

Accordingly, a large volume of studies investigated the impact of training and development on organizational performance. For example, Li et al. (2006) examined the effects of training and development on business performance, selected 194 high-tech companies in China. The study found that HR practices positively influence technological 
performance innovation. Another study by Lu et al (2015) examined the relationship between high-performance human resource practices (HPHRPs) and firm performance in China's service sector. The study's findings confirmed that training and development significantly positively impact firm performance. In their research, Koc et al. (2014) found that training and development positively influence organizational performance in Turkish private companies.

\section{Employees' Empowerment}

Jiang et al (2016) claimed that when employees are motivated, they accomplish organizational goals. Therefore, employees' empowerment should be integrated into the strategies of all organizations. Besides, Jiang et al (2012) argued that employees' productivity could increase when they have become members of a team or the shareholders of a company. The belongingness strives to enhance business success. Thus, this feeling is one of the many kinds of empowerment that affects employees' workplace 2225ehavior (Sirgy and $\mathrm{Wu}, 2009)$.

On the other hand, Kuvaas and Dysvik (2009) state that employee empowerment affects employee outcomes like performance and productivity. Moreover, he found that the empowered employees are more self-independent compared to lower empowered workers. Furthermore, empowered individuals are more committed to their work and more eager to accept duties. Several previous studies revealed that employee empowerment leads to better organizational performance. For example, Meyerson and Dewettinck (2012) investigated the effect of employees empowerment for 226 employees in a Telecommunication Company. The study found that empowerment implementation emphasizes the factors delegation, participating management and encouragement and lead to employees' performance and, in turn, increases the organizational performance. Berraies et al (2014) examined employees' empowerment in 248 ICT Tunisian companies; they found that employees' empowerment positively affects organizational performance.

\section{Compensation and Rewards}

Compensation is the remuneration given to an employee who works for the organization. The organization's compensation system plays a vital role in motivating the firm's performance and increasing productivity (Huselid, 1995). Boyd and Salamin (2001) state that a company's compensation practices are mainly directed by its strategy and business requirements. Equally, employees may also discover varied motivations based on their needs, expertise, lifestyle, or conditions (Gerhart \& Rynes, 2003). Dubrin (2008) claimed that employee performance is linked to a compensation package, contributing to considerable organizational effectiveness.

Consequently, employees need to be given promotions, incentives, and social advantages to encourage them to perform better (Dubrin, 2008). Pfeffer (1994) supported this argument by highlighting that one of the elements of what influential firms do with people is incentive pay. In addition, consumer neuroscience can provide valuable information about the neural correlates of rewards (i.e., monetary rewards) on how individuals can receive, process and making-decision (see Alsharif et al., 2021e; 2021f).

On the other hand, many researchers have examined the impact of monetary and nonmonetary compensation and rewards on employees' and firms' performance. For instance, 
(Frey \& Osterloh, 2002; James, 2005) signify that figurative motives, such as acknowledgement and other non-financial benefits, convey trust, hence increasing intrinsic motivation in the job. Similarly, in their study, Montoro-Sánchez et al. (2011) indicated that symbolic and financial recognition were also important stimulators for developing entrepreneurial behaviours within SMEs. In contrast, Frey and Osterloh (2002) argue that monetary rewards indicate control and micro-management over employees. Another study by Carlson et al (2006) examined incentive compensation in monetary, non-monetary benefits and bonuses for employees in family-owned SMEs. Their research results found that high-performing companies offered more significant financial incentives at all company levels. Similarly, in their study, Hill and Stevens (2001) argued that the more incentives offered, the better a business and its individuals perform.

\section{Business Performance}

Business performance stands for those operations controlled by employees, contribute to the firm's goals and objectives, and quantify an individual's skill level. It refers to the amount and quality of accomplishments made by an individual or a group within an organization (Schermerhorn et al., 2004). According to Rai et al. (2006), business performance is the extent to which a particular business outperforms its competitors. Business performance is a multi-dimensional construct operationalized throughoperational excellence, customer relationship, and revenue growth (Rai et al., 2006). Absar et al. (2010) assert that business performance is contingent upon the employees' competence, knowledge, and experience. Thus, they argue that an influential and distinct human resource bundle enables the organization to accomplish this goal through effective resource utilization, innovation, employee and customer satisfaction, and higher product or service quality.

In the literature, business performance is measured in financial, personnel, and operational performance. Most researchers have investigated a financial perspective, including profitability, return on investment (ROI), return on equity (ROE), sales growth, and revenue growth and earnings growth (Damanpour \& Gopalakrishnan, 2001; Liao et al., 2009; Liao \& Wu, 2009). In contrast, operational success is measured using metrics such as the number of faults in a product or service, the total number of client complaints, market share, and product/service quality (Venkatraman \& Ramanujam, 1986; Wright, Gardner \& Moynihan, 2003). To conduct more in-depth performance analysis, practitioners also use the balanced scorecard established by Kaplan and Norton (2007) to assess business performance in monetary, customer, company's internal procedures, and innovation and learning and growth.

\section{HPHRPs and Business Performance-Linkage}

Human resources are strategic resources essential to the organization as knowledge, skills, abilities, behaviours, and interaction of the employees can influence organizational performance (Osman et al., 2011). In a competitive global business environment, organizations increasingly consider their employees a critical asset that enables them to sustain their competitive edge. (Tsao et al., 2015). Over the past two decades, research on the relationship between HRM practices and business performance has dominated academic and practitioner debates (Purcell \& Kinnie, 2007). In addition, the HRM function has come under pressure to demonstrate its contribution to organizational performance (Sun et al., 
2007). According to Guest (1997), a firm's performance would be accomplished through the employees in the organization. If appropriate HR policies and practices are well established, they can also be assumed to impact firm performance.

Accordingly, the effect of human resource practices on organization-level results has surpassed all other research topics in human resource management. Previous research by Becker and Huselid (1998) indicates that human resource practices, particularly those referred to as 'best' or 'high-performance practices, are associated with business performance, particularly those aimed at increasing employees' abilities and empowerment. Prior empirical studies have shown a significant relationship between HRM practices and organizational performance. Moreover, earlier studies revealed that HRM practices were considered a leading factor in generating firms' growth and enhancing their performance. On the other hand, the literature is divided on why these practices are not always successful once implemented. This leads to whether human resource systems can generate competitive advantages on their own or if they need to be maintained and strengthened by introducing new constructs (Barney and Wright, 1998).

Becker \& Gerhart (1996) introduced the term the "Black Box" to describe the ambiguity of the relationship between HRM practices and a firm's performance for understanding better how and why HRM practices impact individual and organizational-level outcomes, including an organization's competitive advantage (Banks \& Kepes, 2015). Thus, Patel and Cardon (2010) claim that the causal link between HRM practices and the organizational-level outcomes is not thoroughly explained despite the large volume of research to explain the mediating mechanisms within this cause and effect relationship. Armstrong and Taylor (2014) supported this argument; they mentioned two reasons that influence the establishment of a linkage between HRM practices and business performance: First "causal uncertainty" and "contingency factors." These contribute to the phenomenon called the "black box.". Scholars generally agree on two main mediating processes between human resource practices and performance-related outcomes. HRM practices may impact organizational outcomes directly, such as by creating operational efficiencies (Ostroff \& Bowen, 2000) by reducing labour costs (Barney \& Wright, 1998) or by indirectly by increasing the automation of services through the use of technology (Liao et al., 2009).

More precisely, if human resource systems affect firm performance, how does this affect manifest itself? How do these practices affect organizational performance measures? These issues necessitate the refinement and development of the increasingly comprehensive conceptual model of human resource practices - the relationships between firm performance and human resource practices - that incorporate intermediate linkages and boundary conditions(Baron \& Kenny, 1986). Snell et al. (1996) attempted to articulate these intermediary linkages and processes. In other words, it explains how or why there is a relationship between human resource practices and organizational and employee work performance. Therefore, this study introduced innovation as an intervention mediator variable to explain the mechanism to enhance the relationship between HRHRPs and business performance in the banking sector. 


\section{Theoretical Framework and Hypotheses Development}

The purpose of this study is to provide a conceptual model for the relationship between high-performance human resources practices (HPHRPs) and business performance. Further, understand the mediating effect of innovation between HPHRPs and firm performance. In this study, HPHRPs (training and development, employees' empowerment, compensation and reward) constitute the study's independent variables. In contrast, the construct of business performance comprises the dependent variable. The innovation constructs mediate the relationship between the independent and dependent variables. A conceptual model of this study has been developed employing Ability-Empowerment -Opportunity (AMO) theory and Resource-Based View (RBV) theory.

In their overview, Boselie et al. (2005) analyzed 104 empirical research studies that examined the HR practices-performance link; they found that contingency theory, the (RBV), and the AMO are the most frequently used at the organizational level. While (AMO) theory by Appelbaum et al. (2000) is one of the significant theories that can help explain the linking of HR practices at the individual level and explain the employees' behavioural outcomes in organizations. According to Paauwe (2009), AMO theory is often used in HRM-performance research, and more than half of the articles published after 2000 made use of AMO theory. Besides, the AMO theory focuses on the importance of taking into account variables at the individual level like employees' skills and competencies ( $A=$ abilities), their empowerment $(\mathrm{M}=$ empowerment $)$, and their opportunity to participate $(=0)$. These three theories reflect different traditions in HRM research. In contrast,

In contrast, RBV focus on investigating HRM at the organizational level and is mainly interested in its performance effects from a business perspective (Boselie et al., 2005). The RBV concentrates on internal resources and categorizes them into three types: physical, human, and organizational capital resources (Newbert, 2007). According to Wernerfelt (1984, p. 172), a resource is defined as "anything which could strength or weakness of a given firm." Barney $(1991,1995)$ classified resources into tangible and intangible assets such as machinery, brand names, trademarks, efficient procedures, capital, and skilled employees. The RBV provides a theoretical bridge between strategy and HRM by focusing on the internal resources, capabilities, and competencies integral to a firm's success, such as knowledge, learning, and dynamic abilities (Wan \& Yiu, 1999; Wright et al., 2001).

Accordingly, this study proposes a conceptual model based on a comprehensive literature review and theories. Figure 1 presents a conceptual model composed of three variables (a) High-Performance Human Resource Practices (B), innovation (INV), and (C) business performance (BP). The conceptual research framework shows that HPHRPs, an independent variable (employed as an exogenous variable), would be linked with innovation as a mediator variable and business performance as a dependent variable (used as an endogenous variable). The research framework explains that high-performance human resource practices are expected to be positively associated with innovation and subsequently expected to be positively associated with business performance. 


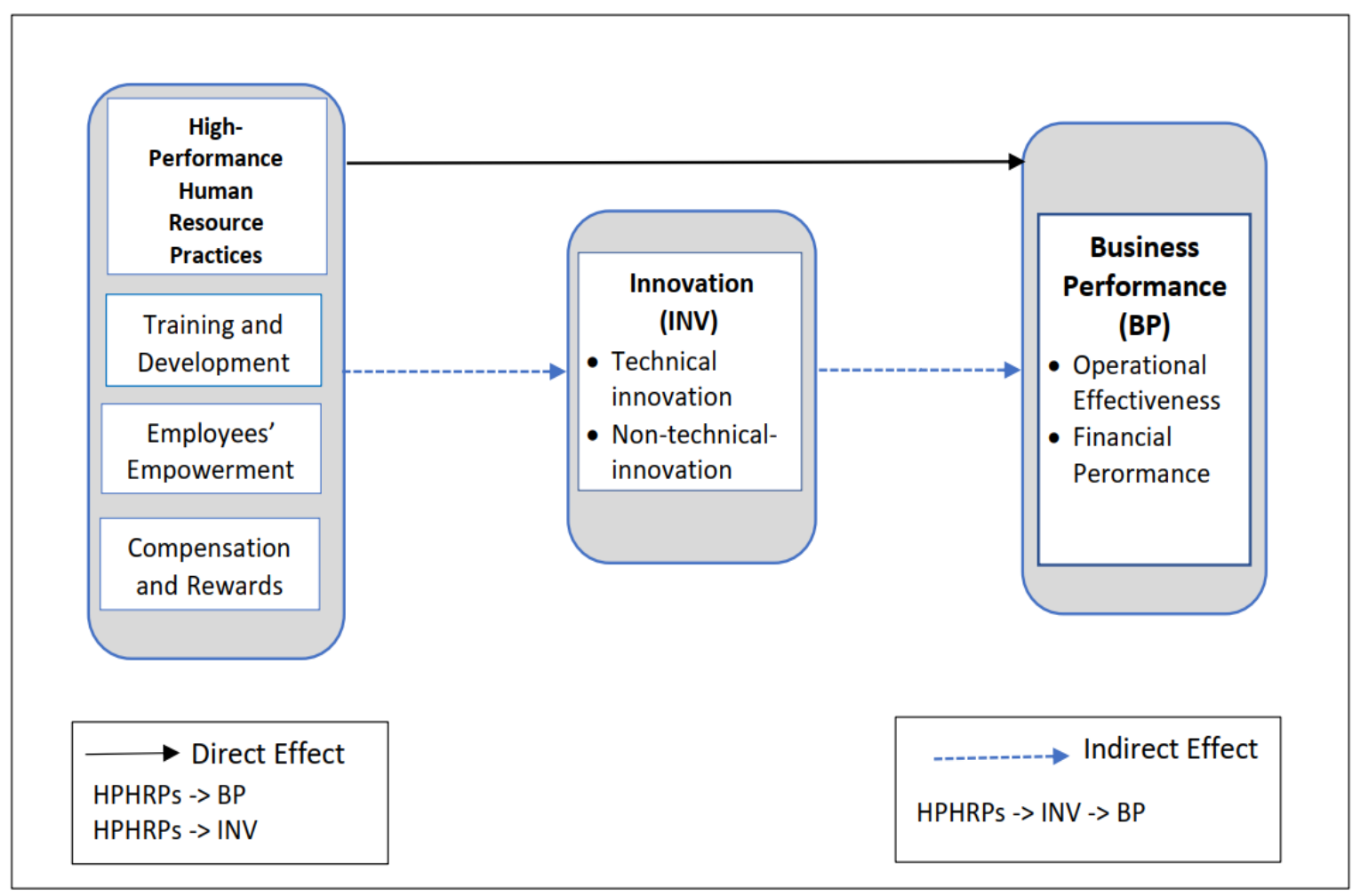

Figure 1 Conceptual Research Model

\section{Conclusion}

The primary purpose of this study is to offer a conceptual model for the relationship between high-performance human resource practices (training and development, empowerment, compensation and rewards) and business performance and what mechanisms of high-performance human resources practices affect the business performance. Where high-performance human resource practices are the main motive of innovation and, in turn, enhance business performance. This positive relationship could exist by selecting proper practices such as well-designed and comprehensive training and development programs that enhance the overall development of the employees and further boost business performance. Additionally, enhancing employees' participation in business management decisions and expressing their views can promote organizational loyalty, thus improving business performance. Further, high compensation and rewards and employees' empowerment enhance and improve organizational performance.

AMO and RBV theories support these relationships, where high-performing human resources practices (training and development programs, employees' empowerment, compensation and rewards) influence business performance. Therefore, firms should develop a solid relationship with their employees to enhance and improve business performance. Consequently, this paper intends to discover the factors that impact business performance. Besides, appeal to more future studies about these factors and presents a general view of what the organization needs to identify related issues with business performance. Finally, future studies are invited to examine the proposed conceptual framework by using advanced statistical methods to investigate the previous hypotheses and provide the findings to help decision-makers in organizations, as well as examine that other high-performance human resource practices such as motivation, career development, teamwork, job security, sharing information, and job description, and their impact on innovation and business performance. 


\section{References}

Absar, M. M. N., Nimalathasan, B., \& Jilani, M. (2010). Impact of HR practices on organizational performance in Bangladesh. International Journal of Business Insights and Transformation, 3(2), 15-19.

Alsharif, A. H., Salleh, N. Z. M., Baharun, R., Hashem E, A. R., Mansor, A. A., Ali, J., \& Abbas, A. F. (2021a). Neuroimaging Techniques in Advertising Research: Main Applications, Development, and Brain Regions and Processes. Sustainability, 13(11), 6488. DOI:https://doi.org/10.3390/su13116488

Alsharif, A. H., Salleh, N. Z. M., \& Baharun, R. (2021b). Neuromarketing: Marketing research in the new millennium. Neuroscience Research Notes, 4(3), 27-35. DOI:https://doi.org/10.31117/neuroscirn.v4i3.79

Alsharif, A. H., Salleh, N. Z. M., \& Baharun, R. (2021c). Neuromarketing: The popularity of the brain-imaging and physiological tools. Neuroscience Research Notes, 3(5), 13-22. DOI:https://doi.org/10.31117/neuroscirn.v3i5.80

Alsharif, A. H., Md Salleh, N. Z., Baharun, R., \& Rami Hashem E, A. (2021d). Neuromarketing research in the last five years: a bibliometric analysis. Cogent Business \& Management, 8(1), 1978620. DOI:https://doi.org/10.1080/23311975.2021.1978620

Alsharif, A. H., Salleh, N. Z. M., \& Baharun, R. (2021e). The neural correlates of emotion in decision-making. International Journal of Academic Research in Business and Social Sciences, 11(7), 64-77. DOI:http://dx.doi.org/10.6007/ijarbss/v11-i7/10075

Alsharif, A. H., Salleh, N. Z. M., \& Baharun, R. (2021f). To better understand the role of emotional processes in decision-making. International Journal of Academic Research in Economics and Management Sciences, 10(2), 49-67. DOI:http://dx.doi.org/10.6007/ijarems/v10-i2/9883

Akhigbe, O. J. (2019). Human Resource Diversity Management Practices and Citizenship Behaviour of Minorities in Nigerian Hospitality Industry.

Aktar, S., Islam, M. S., \& Hossen, S. M. (2012). Human Resource Management Practices and Firms Performance in Bangladesh: An Empirical Study on Pharmaceutical Industry. Asian Business Review, Volume 1(Issue 1).

Alfes, K., Truss, C., Soane, E. C., Rees, C., \& Gatenby, M. (2013). The relationship between line manager behavior, perceived HRM practices, and individual performance: Examining the mediating role of engagement. Human Resource Management, 52(6), 839-859.

Appelbaum, E., Bailey, T., \& Berg, P. (2000). Manufacturing Advantage: Why HighPerformance Work Systems Pay Off. Ithaca, NY: Cornell University Press.

Armstrong, M., \& Baron, A. (2009). Performance management: the new realities. London: Chartered Institute of Personnel and Development, 1998. Performance Management in Action. Current trends and practices.

Armstrong, M., \& Taylor, S. (2014). Armstrong's handbook of human resource management practice. Kogan Page Publishers.

Arthur, J. B. (1994). Effects of human resource systems on manufacturing performance and turnover. Academy of Management Journal, 37(3), 670-687.

Banks, G. C., \& Kepes, S. (2015). The influence of internal HRM activity fit on the dynamics within the "black box". Human resource management review.

Barney, J., \& Wright, P. M. (1998). On becoming a strategic partner: The role of human resources in gaining competitive advantage. Human Resource Management, 37, 3146. 
Baron, R. M., \& Kenny, D. A. (1986). The moderator-mediator variable distinction in social psychological research: Conceptual, strategic, and statistical considerations. Journal of personality and social psychology, 51(6), 1173.

Becker, B., \& Gerhart, B. (1996). The impact of human resource management on organizational performance: Progress and prospects. Academy of Management Journal, 39(4), 779-801.

Becker, B. E., \& Huselid, M. A. (1998). Human resources strategies, complementarities, and firm performance. Academy of Management Annual Meeting, Boston, MA.,

Berraies, S., Chaher, M., \& Yahia, K. B. (2014). Employee empowerment and its importance for trust, innovation and organizational performance. Business Management and Strategy, 5(2), 82-103.

Boadu, F., Dwomo-Fokuo, E., Boakye, J. K., \& Kwaning, C. O. (2014). Training and development: A tool for employee performance in the district assemblies in Ghana. International Journal of Education and Research, 2(5), 130-146.

Bontis, N., Booker, L. D., \& Serenko, A. (2007). The mediating effect of organizational reputation on customer loyalty and service recommendation in the banking industry. Management Decision.

Boselie, P., Dietz, G., \& Boon, C. (2005). Commonalities and contradictions in HRM and performance research. Human Resource Management Journal, 15(3), 67-94.

Boxall, P., \& Macky, K. (2009). Research and theory on high-performance work systems: progressing the high-involvement stream. Human Resource Management Journal, 19(1), 3-23.

Boyd, B. K., \& Salamin, A. (2001). Strategic reward systems: a contingency model of pay system design. Strategic management journal, 22(88), 777-792.

Carlson, D. S., Upton, N., \& Seaman, S. (2006). The Impact of Human Resource Practices and Compensation Design on Performance: An Analysis of Family-Owned SMEs. Journal of Small Business Management, 44(4), 531-543.

Chahal, H., Jyoti, J., \& Rani, A. (2016). The effect of perceived high-performance human resource practices on business performance: Role of organizational learning. Global Business Review, 17(3_suppl), 107S-132S.

Cherif, F. (2020). The role of human resource management practices and employee job satisfaction in predicting organizational commitment in Saudi Arabian banking sector. International Journal of Sociology and Social Policy.

Damanpour, F., \& Gopalakrishnan, S. (2001). The dynamics of the adoption of product and process innovations in organizations. Journal of management Studies, 38(1), 45-65.

Demortier, A.-L. P., Delobbe, N., \& El Akremi, A. (2014). Opening the black box of hr practicesperformance relationship: Testing a three pathways AMO model. Academy of Management Proceedings,

Den Hartog, D. N., Boon, C., Verburg, R. M., \& Croon, M. A. (2013). HRM, communication, satisfaction, and perceived performance a cross-level test. Journal of Management, 39(6), 1637-1665.

Dubrin, J. (2008). Essentials of Management (8 ed.). Cengage Learning.

Elnaga, A., \& Imran, A. (2013). The effect of training on employee performance. European Journal of Business and Management, 5(4), 137-147.

Frey, B., \& Osterloh, M. (2002). Successful Management by Motivation: Balancing Intrinsic and Extrinsic Incentives. Springer. 
Gerhart, B., \& Rynes, S. L. (2003). Compensation: Theory, Evidence, and Strategic Implications. Sage Publications.

Hill, N. T., \& Stevens, K. T. (2001). Structuring compensation to achieve better financial results. Strategic Finance, 82(9), 48.

Huselid, M. A. (1995). The impact of human resource management practices on turnover, productivity, and corporate financial performance. Academy of Management Journal, 38(3), 635-672.

Igbudu, N., Garanti, Z., \& Popoola, T. (2018). Enhancing bank loyalty through sustainable banking practices: The mediating effect of corporate image. Sustainability, 10(11), 4050.

Imran, R., Majeed, M., \& Ayub, A. (2015). Enhancing performance: examining the role played by high performance work system. International Journal of Economics and Financial Issues, 5(1S).

Jackson, S. E., Schuler, R. S., \& Jiang, K. (2014). An aspirational framework for strategic human resource management. The Academy of Management Annals, 8(1), 1-56.

James, H. S. (2005). Why did you do that? An economic examination of the effect of extrinsic compensation on intrinsic motivation and performance. Journal of economic psychology, 26(4), 549-566.

Jiang, X., Flores, H. R., Leelawong, R., \& Manz, C. C. (2016). The effect of team empowerment on team performance: A cross-cultural perspective on the mediating roles of knowledge sharing and intra-group conflict. International Journal of Conflict Management.

Jouda, A. A., Ahmad, U. N. U., \& Dahleez, K. A. (2016). The impact of HRM practices on employees performance: The case of Islamic university of Gaza (IUG) in Palestine. International Review of Management and Marketing, 6(4).

Karam, A. K. D., Ab Yazid, M. S., Khatibi, A., \& Azam, S. F. (2017). Human Resource Management And Talent Management Towards Organizational Success Of Aluminium Industry In United Arab Emirates (UAE): A Measurement Model. European Journal of Human Resource Management Studies.

Kehoe, R. R., \& Wright, P. M. (2013). The impact of high-performance human resource practices on employees' attitudes and behaviors. Journal of Management, 39(2), 366391.

Khan, R. A. G., Khan, F. A., \& Khan, M. A. (2011). Impact of training and development on organizational performance. Global Journal of Management and Business Research, 11(7).

Khoreva, V., \& Wechtler, H. (2018). HR practices and employee performance: The mediating role of well-being. Employee Relations, 40(2), 227-243.

Koc, M., Cavus, M. F., \& Saracoglu, T. (2014). Human resource management practices, job satisfaction and organizational commitment. International Journal of Academic Research in Business and Social Sciences, 4(9), 178.

Koopmans, L., Bernaards, C. M., Hildebrandt, V. H., Lerner, D., de Vet, H. C., \& van der Beek, A. J. (2016). Cross-cultural adaptation of the individual work performance questionnaire. Work, 53(3), 609-619.

Liao, H., Toya, K., Lepak, D. P., \& Hong, Y. (2009). Do they see eye to eye? Management and employee perspectives of high-performance work systems and influence processes on service quality. Journal of Applied Psychology, 94(2), 371. 
Liao, S.-H., \& Wu, C.-C. (2009). The relationship among knowledge management, organizational learning, and organizational performance. International Journal of Business and Management, 4(4), 64-76.

Lu, K., Zhu, J., \& Bao, H. (2015). High-performance human resource management and firm performance: The mediating role of innovation in China. Industrial Management \& Data Systems, 115(2), 353-382.

MacDuffie, J. P. (1995). Human resource bundles and manufacturing performance: Organizational logic and flexible production systems in the world auto industry. Industrial \& Labor Relations Review, 48(2), 197-221.

Messersmith, J. G., Patel, P. C., Lepak, D. P., \& Gould-Williams, J. S. (2011). Unlocking the black box: exploring the link between high-performance work systems and performance. Journal of Applied Psychology, 96(6), 1105.

Meyerson, G., \& Dewettinck, B. (2012). Effect of empowerment on employees performance. Advanced Research in Economic and Management Sciences, 2(1), 40-46.

Nancy, Q. (2013). The impact of hrm practices on organizational performance: the case study of some selected rural banks Kwame Nkrumah University of Science and Technology].

Newbert, S. L. (2007). Empirical research on the resource-based view of the firm: an assessment and suggestions for future research. Strategic management journal, 28(2), 121-146.

Obeidat, S. M., Mitchell, R., \& Bray, M. (2016). The link between high performance work practices and organizational performance: Empirically validating the conceptualization of HPWP according to the AMO model. Employee Relations, 38(4), 578-595.

Osman, I., Ho, C. F., Theresa, \& Galang, M. C. (2011). Are human resource departments really important? An empirical study on Malaysian small and medium enterprises (SMEs) in the Service Sector. International Journal of Business and Management, 6(2), p147.

Ostroff, C., \& Bowen, D. E. (2000). Moving HR to a higher level: HR practices and organizational effectiveness. In K. J. Klein, \& S. W. J. Kozlowski (Eds.), Multilevel theory, research, and methods in organizations. Jossey-Bass.

Paauwe, J. (2009). HRM and performance: Achievements, methodological issues and prospects. Journal of management Studies, 46(1), 129-142.

Patel, P., \& Cardon, M. (2010). Adopting HRM practices and their effectiveness in small firms facing product-market competition. Human Resource Management, 49(2), 265-290.

Pfeffer, J. (1994). Competitive advantage through people. California management review, 36(2), 9.

Rai, A., Patnayakuni, R., \& Seth, N. (2006). Firm performance impacts of digitally enabled supply chain integration capabilities. Mis Quarterly, 225-246.

Sadek, H., Youssef, A., Ghoneim, A., \& Tantawy, P. (2012). Measuring the effect of customer relationship management (CRM) components on the non financial performance of commercial banks: Egypt case.

Saleem, D. I., \& Khurshid, A. (2014). Do human resource practices affect employee performance? Saleem, I. \& Khurshid, A.(2014). Do Human Resource Practices affect Employee Performance, 669-688.

Schermerhorn, J. R., Hunt, J. G., \& Osborn, R. (2004). Core concepts of organizational behavior. John Wiley \& Sons Incorporated.

Scrace, T., \& McAulay, L. (1997). Recharging service costs in financial services: is there an optimum charge? MANAGEMENT ACCOUNTING-LONDON-, 75, 40-43. 
Singh, S., Darwish, T. K., \& Potočnik, K. (2016). Measuring organizational performance: A case for subjective measures. British Journal of Management, 27(1), 214-224.

Smith, S. A., \& Mazin, R. A. (2011). The HR answer book: An indispensable guide for managers and human resources professionals. Amacom Books.

Sun, L.-Y., Aryee, S., \& Law, K. S. (2007). High-performance human resource practices, citizenship behavior, and organizational performance: A relational perspective. Academy of management Journal, 50(3), 558-577.

Taufek, F. H. M., \& Mustafa, M. (2018). The effect of training and development towards employee performance: A case study in proton Tanjung Malim. Global Business and Management Research, 10(3), 777.

Tsao, C.-W., Newman, A., Chen, S.-J., \& Wang, M.-J. (2015). HRM retrenchment practices and firm performance in times of economic downturn: exploring the moderating effects of family involvement in management. The International Journal of Human Resource Management, 1-20.

Ulrich, D., \& Lake, D. (1991). Organizational capability: Creating competitive advantage. Academy of Management Perspectives, 5(1), 77-92.

Van De Voorde, K., \& Beijer, S. (2015). The role of employee HR attributions in the relationship between high-performance work systems and employee outcomes. Human Resource Management Journal, 25(1), 62-78.

Wernerfelt, B. (1984). A resource-based view of the firm. Strategic management journal, 5(2), 171-180.

Wright, P. M., Gardner, T. M., Moynihan, L. M., \& Allen, M. R. (2005). The relationship between HR practices and firm performance: Examining causal order. Personnel Psychology, 58(2), 409-446. 